\title{
The search for "hot shales" in the western Kufra Basin, Libya: Geochemical and mineralogical characterisation of outcrops, and insights into latest Ordovician climate
}

\author{
Guido Meinhold ${ }^{1,2, *}$, Daniel P. Le Heron ${ }^{3}$, Mohamed Elgadry ${ }^{4}$, Yousef Abutarruma ${ }^{5}$ \\ ${ }^{1}$ CASP, West Building, 181A Huntingdon Road, Cambridge CB3 0DH, United Kingdom \\ 2 Department of Sedimentology and Environmental Geology, Geoscience Center, University of Göttingen, \\ Goldschmidtstrasse 3, 37077 Göttingen, Germany \\ ${ }^{3}$ Department of Earth Sciences, Queen's Building, Royal Holloway University of London, Egham, TW200EX, \\ United Kingdom \\ ${ }^{4}$ Libyan Petroleum Institute, Gergarish Road, P.O. Box 6431, Tripoli, Libya \\ ${ }^{5}$ Mellitah Oil \& Gas B.V., Dat Al Imad Complex Tower 5, Floor 13, P.O. Box 91651, Tripoli, Libya \\ * Corresponding author, email: guido.meinhold@geo.uni-goettingen.de
}

\begin{abstract}
Across the Saharan platform, mudrocks of latest Ordovician-Silurian age (the Tanezzuft Formation) are a major source rock interval for Palaeozoic petroleum systems, but source rock quality is variable and difficult to predict. In the Kufra Basin of southern Libya, evidence for organic enrichment in this formation is scarce. This paper presents the results of a spectral gamma-ray study of siliciclastic sedimentary rocks in Jabal Eghei at the western margin of the basin. The study spans the Ordovician-Silurian interval together with overlying Mesozoic strata and was conducted at outcrop using a hand-held gamma-ray spectrometer. Element concentrations of potassium (K), uranium (U) and thorium (Th) were collected from mudrock and sandstone successions to identify natural background values of these elements for different formations. Uranium contents were used to identify possible "hot shales" with source rock potential. This study shows that sandstones and mudrocks are clearly discriminated by their K, U and Th contents. Most sandstones have $<0.3 \%$ of $\mathrm{K},<4 \mathrm{ppm}$ of $\mathrm{U}$ and $<10 \mathrm{ppm}$ of Th. In contrast, the mudrocks show values of $>0.3 \%$ of $\mathrm{K},>4 \mathrm{ppm}$ of $\mathrm{U}$, and $>10 \mathrm{ppm}$ of Th. Based on gamma-ray spectrometry, the Tanezzuft Formation is divisible into lower, middle and upper members. There is a significant difference in $\mathrm{K}$ content between the three members. Exposures of the lower member show K contents less than $0.5 \%$; those from the middle member are between 1.5 and $3.6 \%$; and the upper member has $\mathrm{K}$ contents between 0.5 and $1.5 \%$. Notably, U values $>10$ ppm are restricted to the upper member, indicating the presence of "warm shales" in Jabal Eghei. There is a progressive increase of $\mathrm{Th} / \mathrm{K}$ ratios from the basal part of the Tanezzuft Formation towards the upper member. The decrease in $\mathrm{K}$ content and increase in $\mathrm{Th} / \mathrm{K}$ ratios between the middle and the upper members of the Tanezzuft Formation can be explained by a mineralogical change, confirmed by X-ray diffraction analyses on representative samples. The total volume of clay minerals is $64 \%$ higher in the upper member than in the middle member, with kaolinite predominant. These changes in composition suggest a change towards a more weathered sediment source, which was probably caused by increased continental weathering due to climate change from icehouse to greenhouse conditions at the Ordovician-Silurian transition.
\end{abstract}

Keywords: Libya, Kufra Basin, Palaeozoic, Tanezzuft Formation, gamma-ray spectrometry, geochemistry, source rocks. 
A key risk for hydrocarbon exploration in southern Libya is source rock presence. In particular, the quality of "hot shales" within the early Silurian part of the Tanezzuft Formation is highly variable and notoriously difficult to predict (e.g., Lüning et al. 2000; Meinhold et al. 2013a,b). In borehole wireline logs, a radioactive peak on the gamma-ray log can be used to identify the "hot shales". This radioactivity is commonly attributed to a high uranium (U) content resulting from organic matter enrichment (e.g., Stocks and Lawrence 1990; Lüning et al. 2000). The so-called "hot shales" are commonly concealed; if they are exposed at outcrop, they are often deeply weathered and are devoid of organic matter as a result of oxidation (e.g., Meinhold et al. 2013b). Hand-held gamma-ray measurements on Tanezzuft Formation exposures are commonly used to identify potential source rocks on the basis that they commonly have elevated U contents (e.g., Lüning et al. 2000, 2003; Lüning and Fello 2008). This is based on the assumption that $\mathrm{U}$ is not able to migrate as a result of weathering processes during rock exposure at the surface, an assumption that has been the subject of some debate (e.g., Chabaux et al. 2003). Moreover, U adsorption on organic matter depends on parameters such as the type of organic matter, degree of thermal maturity, ionic strength, and pH and Eh conditions (Semião et al. 2010; Bachmaf and Merkel 2011). The total U signal is composed of detrital U-bearing phases and authigenic U. In any outcrop or borehole section of the Tanezzuft Formation, the gamma-ray signal of the wireline log has contributions not only from $U$ but also from the thorium (Th) and potassium (K) contents (Serra 1984). Therefore, a radioactive peak on the gamma-ray log may also be caused by elevated Th and $\mathrm{K}$ contents but may be unrelated to $\mathrm{U}$.

In Jabal Eghei, exposures of the Ordovician Hawaz and Mamuniyat Formations, the latest Ordovicianearly Silurian Tanezzuft Formation and unconformably overlying Mesozoic sandstones were analysed for their K, $\mathrm{U}$ and Th contents using a hand-held gamma-ray spectrometer. The aim of this study was two-fold: (1) to show that the $\mathrm{Th} / \mathrm{K}$ ratio may be used as a chemostratigraphic indicator (particularly useful given the paucity of macrofossils); and (2) to document the U content in the search for "hot shales" within the Tanezzuft Formation at Jabal Eghei.

Until recently, only one study had collected spectral gamma-ray measurements on Tanezzuft Formation mudrocks from the western Kufra Basin. Lüning and Fello (2008) measured U values of up to 11 ppm indicating a moderate $\mathrm{U}$ enrichment for the basal Tanezzuft Formation, which they interpreted as a relic of the radioactive "hot shale" (Lüning et al. 2003). Lüning and Fello (2008, p. 11) pointed out that further studies of outcrops in the Kufra Basin "are still needed to demonstrate what the maximum U values in this stratigraphic horizon are so as to better assess the source risk in this basin" (sic).

\section{Geological setting}

The Kufra Basin occupies an area of about 400,000 km² in SE Libya, northern Chad, NW Sudan and eastern Egypt (Fig. 1). It is filled by an up to $2600 \mathrm{~m}$ thick succession of marine and continental Palaeozoic and Mesozoic sandstones and mudrocks (e.g., Bellini et al. 1991). In Libya, exposures are limited to the basin margins: Jabal Dalma (alternate spelling: az-Zalmah), Jabal Asba (alternate spelling: Azbah), Jabal Arkenu and Jabal Eghei. The present study focuses on Jabal Eghei, on the western margin of basin. This paper documents sections located $\sim 100$ km north of the Libya-Chad border (Fig. 1). 
A detailed description of the stratigraphy and facies interpretation of the sedimentary strata of Jabal Eghei is given by Le Heron et al. (2013, 2015) and is summarised briefly below. The oldest studied succession, the Hawaz Formation, composed of a cross-bedded and a Skolithos-burrowed sandstone facies association, occupies the westernmost part of the study area, although isolated outcrops have also been found near the eastern margin of the area. The complete thickness of the Hawaz Formation is unknown, but may exceed $100 \mathrm{~m}$ (Fig. 2). The maximum logged thickness is $85 \mathrm{~m}$ (Le Heron et al. 2015).

The Hawaz Formation is unconformably overlain by the Mamuniyat Formation which is divided into two members: (1) a heterolithic basal section, fining up into mudrocks and (2) a thick succession of massive to climbing dune cross-bedded, fine- to medium-grained sandstones with ubiquitous dewatering structures. The Mamuniyat Formation is up to $145 \mathrm{~m}$ thick (Fig. 2). As this thickness was observed where the Mamuniyat Formation is unconformably overlain by Mesozoic sandstone (Le Heron et al. 2015), it should be regarded as a minimum value.

The Tanezzuft Formation at Jabal Eghei includes from the base up (1) a calcareous, bryozoa-bearing sandstone immediately above the basal contact of the formation with the underlying Mamuniyat Formation, (2) a Planolites-bearing sandstone, (3) a putative glacial striated surface, (4) an interval with calcareous, pebble-sized clasts (?dropstones) below and above this surface, (5) a second bioturbated horizon, and further up a mudrock succession with (6) a marker bed containing well-preserved graptolites (Page et al. 2013) (Figs. 2 and 3). The Tanezzuft Formation has a thickness of up to $50 \mathrm{~m}$ (Fig. 2). An unconformity beneath the overlying Mesozoic sandstone accounts for thickness variations.

Hand-held gamma-ray measurements enable understanding of the Tanezzuft Formation to be refined by dividing it into three members. The lower member includes the bryozoa-bearing sandstone and all sediments up to the first Planolites-bearing sandstone; the middle member forms the succession up to the graptolite-bearing marker bed; and the mudrocks above from the base of the graptolite-bearing marker bed form the upper member (Fig. 3).

The youngest sedimentary succession studied is the Mesozoic sandstone (commonly referred to as "Nubian Sandstone"), which comprises cross-bedded, coarse-grained sandstones and conglomerates. An unconformity at the base of this unit locally accounts for removal of substantial parts of the early Palaeozoic stratigraphy (Figs. 3 and 4).

\section{Material and methods}

A portable hand-held gamma-ray spectrometer from GF Instruments (formerly Geofyzika, Brno) was used during fieldwork in November-December 2008 to determine the in situ concentration of radioactive K, U and Th on outcrop exposures. This method is simple, non-destructive and cost-effective, and it allows rapid collection of data in the field. Following Lüning and Fello (2008), a 3-minute measuring interval was adopted, allowing quantitative reproducible results. The localities where measurements were performed are shown in Figure 1. The geographic coordinates and the full set of data are provided as Supplementary material.

To deduce the mineralogical composition of the Tanezzuft Formation sediments, X-ray diffraction (XRD) analyses were performed on three representative samples. They were run on a Panalytical X'Pert pro diffractometer machine fitted with a $\mathrm{Cu}$ X-ray tube at the School of Ocean and Earth Science, University of Southampton. The machine operating conditions were set at $35 \mathrm{kV}, 40 \mathrm{~mA}$ utilising automatic slits and a step size of $0.02^{\circ} 2 \varnothing$ at 1 second/ step. The samples were prepared as randomly oriented powder samples to which an internal standard of $25 \%$ by weight of corundum was added. The samples were ground under isopropanol in a McCrone mill for 8 
minutes. Samples were side-loaded, to avoid preferred orientation, and X-rayed. Quantitative analysis of each sample was undertaken using a least-squares method. The XRD data are summarised in Table 1.

\section{Results}

In total, 179 in situ measurements of $\mathrm{K}, \mathrm{U}$ and Th were performed covering outcrop exposures of the Hawaz, Mamuniyat and Tanezzuft Formations and of the Mesozoic sandstone. Of these, 117 measurements were obtained from the Tanezzuft Formation. Measurements were carried out vertical profiles (Figs. 5 and 6) and on single outcrops. In the following sections, the data are discussed to discriminate (i) between sandstones and mudrock, (ii) between sandstones from different formations, and (iii) between different members of the Tanezzuft Formation. The first point is of special importance for subsurface (wireline log) data where only gamma-ray (K, U, Th) values are available without information about the corresponding lithologies. The other points are of importance for distinguishing the sedimentary succession in the western Kufra Basin based on $\mathrm{K}$, $\mathrm{U}$, and Th contents and for identifying "hot shale" intervals.

Sandstone and mudrock discrimination

Sandstones and mudrocks can be discriminated in the present study based on their K, U and Th values (Fig. 7AD). A remarkable feature is the low $\mathrm{K}$ content $(<0.3 \%)$ for almost all analysed sandstone samples; the exceptions are a few fine-grained sandstones from the Tanezzuft Formation. Furthermore, most of the sandstones have $\mathrm{U}$ and Th contents less than 4 and 10 ppm respectively. Except for one measurement, the Th/U ratios are between 1 and 5 and thus in the same range as the mudrocks. The mudrocks have $U$ and Th contents of 4 to 16 and 10 to $26 \mathrm{ppm}$ respectively, and the majority have $\mathrm{K}$ contents between 0.4 and $3.6 \%$.

Sandstone discrimination

Cross-plots of $\mathrm{U}$, Th and $\mathrm{K}$ contents for sandstones of the Hawaz, Mamuniyat and Tanezzuft formations and the Mesozoic sandstone are shown in Fig. $7 \mathrm{E}-\mathrm{H}$. All analysed sandstones have $\mathrm{K}$ contents $<0.3 \%$; the exceptions are a few fine-grained sandstones from the Tanezzuft Formation, with $\mathrm{K}$ contents between 1.5 and $2 \%$ and around 3 $\%$ respectively. Hawaz Formation and Mamuniyat Formation sandstones and the Mesozoic sandstone show a similar range for Th and $\mathrm{U}$ contents, with 2 to $10 \mathrm{ppm}$ for Th and 1 to $3.5 \mathrm{ppm}$ for $\mathrm{U}$. The exceptions are three Mamuniyat Formation sandstones which are fine-grained and micaceous. By comparison, fine-grained, micaceous sandstones from the Tanezzuft Formation have slightly elevated values of both Th (6-18 ppm) and U (3.5-5.5 $\mathrm{ppm})$.

Tanezzuft Formation discrimination

Hand-held gamma-ray measurements of the Tanezzuft Formation indicate differences in $\mathrm{K}$ content between the three members (Fig. 8). The lower member shows $\mathrm{K}$ contents of $<0.5 \%$. The middle member has $1.5-3.6 \% \mathrm{~K}$, whereas the upper member exhibits intermediate values $(0.5$ and $1.5 \% \mathrm{~K})$. The Th and $\mathrm{U}$ contents for samples from the lower member and for the middle and upper members are between 6 and $26 \mathrm{ppm}$ and 3 and $16 \mathrm{ppm}$ respectively, with $\mathrm{U}$ values $>10 \mathrm{ppm}$ restricted to the upper member. Samples with $\mathrm{Th} / \mathrm{U} \leq 2$ are restricted to a 
number of samples from the lower member and the upper member (Figs. 8C-D). The majority of the samples from

\section{Discussion}

Origins of the gamma-ray signal

Before interpreting the observed $\mathrm{K}, \mathrm{U}$ and Th values, it is useful to discuss the primary factors controlling the $\mathrm{K}$, $\mathrm{U}$ and Th signals and the secondary parameters which modify these values during weathering and diagenesis. The distribution of $\mathrm{K}, \mathrm{U}$ and $\mathrm{Th}$ in sedimentary rocks is mainly controlled by the provenance of the clastic components, and by the physical and chemical stability of these components during the sedimentary cycle. The most important factors controlling the $\mathrm{U}$ content in sedimentary rocks are as follows (Raiswell and Berner 1987; Wignall and Myers 1988; Klinkhammer and Palmer 1991; Jones and Manning 1994; Lüning and Kolonic 2003; Algeo and Maynard 2004; Semião et al. 2010; Bachmaf and Merkel 2011):

- Lithology of the host sediment (e.g., whether mudrock or sandstone);

- The primary concentration of $U$ in the water column;

- The availability, type and concentration of a sorbent for U (e.g., organic matter, phosphate);

- The sedimentation rate and duration of anoxia;

- The ionic strength, and $\mathrm{pH}$ and Eh conditions;

- The position of the redox boundary relative to the sediment-water interface; and

- The degree of burial and thermal maturation.

The commonly observed close relationship between U and TOC contents (Stocks and Lawrence 1990; Lüning and Kolonic 2003) is based on the fact that in seawater $\mathrm{U}^{6+}$ is carried in solution as uranyl carbonate complexes which 'precipitate' under oxygen-depleted, strongly reducing conditions within the sediment during deposition (Wignall and Myers 1988; Klinkhammer and Palmer 1991). $\mathrm{U}^{6+}$ may thus be reduced to the immobile $\mathrm{U}^{4+}$, leading to $\mathrm{U}$ enrichment in sediments in anoxic conditions, while oxidising conditions can lead to U loss from sediments. The authigenic $U$ can be calculated by using following equation: authigenic $U=($ total $U)-T h / 3$ (Wignall and Myers 1988). Uranium is commonly thought to be associated with the organic matter in the sediment rather than the clay minerals. However in marine sediments, organic matter also seems to be associated with various clay minerals due to adsorption/entrapment processes (Bader et al. 1960; Bishop and Philp 1994). Thus, U content may also be indirectly related to clay mineral composition (Chabaux et al. 2003). Uranium also occurs in detrital fractions but detrital U concentrations in sediments usually co-vary with those of K and Th (Wignall and Myers 1988). For example, in Frasnian successions in western Algeria, the authigenic U enrichment in organic-rich mudrocks is independent of the purely detrital $\mathrm{K}$ and $\mathrm{Th}$, as evidenced by the general decoupling of the $\mathrm{U}$ peak versus the $\mathrm{K}$ and Th contents (Lüning et al. 2004).

The relationship between $\mathrm{U}$ and TOC (total organic carbon) content was recently investigated on core material from Dor el Gussa, eastern Murzuq Basin (Meinhold et al. 2013b). There, it was shown that the TOC content does not always correlate with U concentrations. For example, a TOC content of $1.7 \mathrm{wt} \%$ is associated 
with a $U$ value of $4.6 \mathrm{ppm}$, while the highest $U$ value of $7.1 \mathrm{ppm}$ corresponds to a low TOC value of only 0.29 carefully, especially in the range of low TOC values. Consequently, caution is required when using U contents determined with a hand-held gamma-ray spectrometer to consider whether these values usefully represent a proxy for former TOC values of the strata.

Thorium is relatively immobile and is present mainly in the detrital clay fraction (Serra 1984). Other possible sources include heavy minerals such as monazite and zircon. Thorium is unaffected by redox conditions and remains as insoluble $\mathrm{Th}^{4+}$ in the marine environment.

"Average Shale", which integrates the composition of the upper continental crust, has a Th/U ratio of 3.8 (Taylor and McLennan 1985). Under normal oxidising conditions, marine mudrock should have a Th/U ratio equal to or higher than 3.8. However, some $U$ may sequester during early diagenesis due to reducing conditions in pore waters related to organic decomposition. Wignall and Twitchett (1996) suggested that environments characterised by anoxic conditions lead to mudrock $\mathrm{Th} / \mathrm{U}$ ratios of 0 to 2 , and this general guideline has been followed in subsequent studies.

Potassium is mainly associated with K-feldspar (e.g., orthoclase), mica (muscovite), clay minerals (illite group) and salt such as potassium chloride (sylvine) (Heier and Billings 1970; Serra 1984). Under oxidising conditions due to weathering (humid and warm climate), $\mathrm{K}$ is easily mobilised and removed from the sediment.

The abundance of $\mathrm{K}, \mathrm{U}$ and $\mathrm{Th}$ in various rock-forming minerals is summarised in Table 2 . These values clearly show that quartz arenites have a low gamma-ray signal because of the absence of K-, U- and Th-bearing minerals. An exception occurs where there is zircon enrichment in heavy mineral layers. The presence of orthoclase, mica and clay minerals will contribute to the gamma-ray signal. Ratios of $\mathrm{Th} / \mathrm{K}$ enable identification of the dominant mineral type (Fig. 8F), with increasing Th/K values from glauconite $\rightarrow$ muscovite $\rightarrow$ illite $\rightarrow$ mixed-layer clays (illite-smectite) $\rightarrow$ kaolinite $\rightarrow$ chlorite $\rightarrow$ bauxite (Bateman 1985). Here, we focus on the clay minerals. In nature, the most common clay minerals in the sedimentary record are kaolinite, illite, smectite (montmorillonite) and chlorite. Kaolinite forms predominantly during eodiagenesis by intense leaching of feldspars and mica in warm and humid continental environments (Worden and Morad 2003). Illite and smectite (montmorillonite) are mixed-layer clay minerals, which are abundant in clay mineral assemblages that developed from mica-rich crystalline rocks (e.g., granite, mica schist) following incomplete weathering (Füchtbauer 1988; Worden and Morad 2003). Chlorite may form from smectite by Mg uptake (Füchtbauer 1988) or during mesodiagenesis as a result of the breakdown of mafic silicates (Worden and Morad 2003).

Sample discussion

The analysed sandstones and mudrocks are clearly discriminated by their K, U and Th contents. Most sandstones have $<0.3 \%$ of $\mathrm{K},<4 \mathrm{ppm}$ of $\mathrm{U}$ and $<10 \mathrm{ppm}$ of $\mathrm{Th}$, whilst mudrocks show values of $>0.3 \%$ of $\mathrm{K},>4 \mathrm{ppm}$ of $\mathrm{U}$, and $>10 \mathrm{ppm}$ of Th (Figs. 7 and 8). The exceptions are fine-grained, micaceous sandstones which show geochemical signatures similar to those of mudrocks. It is important to consider that the hand-held gamma-ray spectrometer gathers K, U and Th values over a several $\mathrm{cm}$ thick interval, thus "smearing" the signal. For example, a few thin, micaceous laminae within a $30 \mathrm{~cm}$ thick sandstone bed could contribute notably to the $\mathrm{K}$, U and Th content of the interval. There are no other significant differences in geochemical composition of the sandstones, with the exception of samples from the Tanezzuft Formation (Figs. 7E-H and 8). The latter have elevated contents 
of $\mathrm{K}, \mathrm{U}$ and $\mathrm{Th}$, which can be explained by elevated contents of K-feldspar and clay minerals. Samples from the relatively high maturity of these sandstones: they are quartz arenites with negligible feldspar and mica contents.

The geochemical signature of the Tanezzuft Formation (Fig. 8) shows K values in the lower member of $<0.5 \%$, those in the middle member $>1.5 \%$, and the upper member has values between 0.5 and $1.5 \%$. Exposures with $U$ contents $>10$ ppm are restricted to the upper member ("warm shales") and show authigenic U enrichment. Moreover, these mudrocks have $\mathrm{Th} / \mathrm{U}$ ratios $<2$, which would suggest an anoxic environment during their deposition (Wignall and Twitchett 1996). Graptolite preservation supports this, indicating a dysoxic to anoxic environment (Page et al. 2013).

Secondary enrichment of $U$ due to recent weathering seems unlikely. For example, mudrocks from borehole CDEG-2a at Dor el Gussa, in the eastern margin of the Murzuq Basin, do not show a difference of U content between weathered and unweathered sections (Meinhold et al. 2013b). Furthermore, Fello et al. (2006) noted that the $\mathrm{U}$ content of analysed mudrocks in the Ghat area do not seem to have been affected significantly by recent weathering processes: thus, no major uranium mobilisation has taken place.

The distinct $\mathrm{K}$ contents within the lower, middle and upper members of the Tanezzuft Formation can be explained by a mineralogical change and may simply reflect variations in the clay mineral composition, as shown in Figure 8E-F. Focusing on the middle and upper members only, the $\mathrm{Th} / \mathrm{K}$ ratios (3.5-12) of the middle member suggest prominent mixed-layer clays while $\mathrm{Th} / \mathrm{K}$ ratios $(12-28)$ of the upper member indicate the dominance of kaolinite. Mudrocks with U enrichment are restricted to the kaolinite-rich succession.

Low K values of the U-enriched Tanezzuft Formation mudrocks at the western margin of the Kufra Basin could be explained by post-depositional removal of potassium due to intense surface weathering. However, this seems unlikely because whole-rock geochemical data from borehole CDEG-2a in Dor el Gussa do not show a change in K content between heavily weathered and unweathered Tanezzuft Formation mudrocks (Meinhold et al. 2013b). Transferring this observation to Jabal Eghei, we therefore suggest that the low K content in the upper member of the Tanezzuft Formation is of primary sedimentary origin. This implies that the sediment provenance or the depositional environment (or both) underwent a major change from the middle to the upper member of the Tanezzuft Formation.

X-ray diffraction analyses on representative samples reveal the mineralogical differences between the three members of the Tanezzuft Formation (Table 1). Focusing on the middle and upper members only, there is a clear decrease in K-feldspar content from about $6.7 \%$ in the middle member to zero in the upper member, accompanied by an increase in total clay mineral content from about $30 \%$ in the middle member to $50 \%$ in the upper member. Kaolinite is the most prominent clay mineral. The middle and upper members have $\sim 16 \%$ and $\sim 28$ $\%$ kaolinite, respectively, representing an increase of approximately $70 \%$. Again, the kaolinite is most likely of detrital sedimentary origin. The progressive decrease in K-feldspar accompanied by a progressive increase in kaolinite, total clay mineral content and in $\mathrm{Th} / \mathrm{K}$ ratios from the middle member to the upper member may be explained by a change in provenance or of weathering conditions (or both) during deposition.

Graptolites from the upper member of the Tanezzuft Formation are monospecific with Normalograptus kufraensis nov. sp. (Page et al. 2013). Although further data on the stratigraphy of the outcrop or on the evolution of Normalograptus lineages are needed, the graptolites may be of Hirnantian or younger age (Page et al. 2013), and hence, the Tanezzuft Formation in Jabal Eghei may record the Ordovician-Silurian transition. 
The graptolite-bearing marker bed forms the base of, or at least belongs to the lower part of, the upper (Hirnantian) and the Early Llandovery (Rhuddanian), which was not restricted to peri-Gondwana but has been described worldwide, e.g. from the Yangtze platform of South China (e.g., Xu et al. 2004). This biofacies change was accompanied by a climate change, with a cold and dry climate during the Hirnantian glaciation and increasing temperature (global warming) throughout the latest Hirnantian into the early Silurian (e.g., Brenchley et al. 2003, 2006). It seems that the studied Tanezzuft Formation sections in Jabal Eghei span an icehouse to greenhouse transition. The middle member of the Tanezzuft Formation (Figs. 3 and 9), containing ?dropstones, K-feldspar and the "mixed-layer clays", was deposited during the last icehouse period, most likely in the transitional phase to greenhouse conditions, whilst marine transgression was underway (Fig. 10). The upper member of the Tanezzuft Formation (Figs. 3 and 9), containing the graptolite-bearing bed and kaolinite-rich succession, was likely deposited during greenhouse conditions (warm and at least seasonally humid climate) (Fig. 10). The physic-chemical and thermodynamic parameters changed from icehouse to greenhouse conditions. This may have promoted the formation of kaolinite-rich soils, which were eroded and transported toward the sea by rivers. Therefore, the presence of detrital kaolinite in the Tanezzuft Formation sediments may suggest relative proximity to the palaeoshoreline and thus supply with fresh water from the continent. This is in good agreement with a facies map for the early Silurian of southern Libya and neighbouring regions (fig. 16 in Meinhold et al. 2013b). Uranium enrichment may be explained by $U$ retention onto pyrite since the preservation of the graptolites suggests deposition under dysoxic to anoxic conditions (Page et al. 2013). The sediment-water interface changed from oxic to dysoxic or anoxic depositional conditions probably due to melting glaciers which caused a sea level rise in the latest Ordovician-earliest Silurian (Fig. 10).

\section{Conclusions}

Hand-held gamma-ray measurements in outcrop at Jabal Eghei reveal distinct K, U and Th contents for sandstones and mudrocks, which reflect the different mineralogical composition of these strata. Sandstones have low contents of $\mathrm{K}(<0.3 \%), \mathrm{U}(<4 \mathrm{ppm})$ and $\mathrm{Th}(<10 \mathrm{ppm})$; they are quartz arenites. Mudrocks show higher values of $\mathrm{K}, \mathrm{U}$ and Th because they are enriched in clay minerals. There is a marked difference in $\mathrm{K}$ content and $\mathrm{Th} / \mathrm{K}$ ratios between the lower, middle and upper members of the Tanezzuft Formation. Uranium values $>10 \mathrm{ppm}$ are restricted to the upper member and indicate the presence of "warm shales". The progressive decrease in K content and increase in $\mathrm{Th} / \mathrm{K}$ ratio can be explained by a change in clay mineral composition, with a progressive increase of kaolinite towards the upper member. Kaolinite presence probably suggests a relatively humid and warm climate during deposition, if recycling of kaolinite from older successions is excluded. If so, the change in clay mineral composition may reflect the climate change from the Late Ordovician icehouse to the Silurian greenhouse, accompanied by a sea level rise.

The present study clearly shows the applicability of hand-held gamma-ray measurements for chemostratigraphy even in heavily weathered sections in the Libyan Sahara. The identification of mudrocks with elevated U contents suggests the presence of "warm shales" at the western margin of the Kufra Basin. Outcrops further south of the present study area, in the Chad border area, expose a greater thickness of the Tanezzuft Formation; study of these sections is likely to shed further light on faunal and mineralogical changes at the Ordovician-Silurian transition, hence providing further insight into the source rock potential at the flanks of this huge basin. 


\section{Acknowledgements}

The authors are grateful to Faraj Said (National Oil Corporation, Tripoli, Libya), Ahmed I. Asbali (Arabian Gulf Oil Company, Benghazi, Libya), Ramadan Aburawi and Bourima Belgasem (Libyan Petroleum Institute, Tripoli, Libya) for their scientific support and guidance during the project work in Libya. We also would like to thank the logistics team, provided by Bashir Grenat, for assistance in the field. The administrative and logistical support of staff at the Libyan Petroleum Institute is gratefully acknowledged. Richard Pearce (University of Southampton, United Kingdom) is thanked for providing the XRD data. The consortium of oil and gas industry subscribers is thanked for its financial support to the CASP project work in Libya. We are very grateful to Christopher Tiratsoo (Beaconsfield, United Kingdom) and Stephen Vincent (CASP, Cambridge, United Kingdom) for commenting on this work during pre-review.

\section{References}

Algeo TJ, Maynard JB (2004) Trace-element behavior and redox facies in core shales of upper Pennsylvanian Kansas-type cyclothems. Chemical Geology 206:289-318.

Bachmaf S, Merkel BJ (2011) Sorption of uranium(VI) at the clay mineral-water interface. Environmental Earth Sciences 63:925-934.

Bader RG, Hood DW, Smith JB (1960) Recovery of dissolved organic matter in seawater and organic sorption by particulate material. Geochimica et Cosmochimica Acta 19:236-243.

Bateman RM (1985) Open-hole log analysis and formation evaluation. International Human Resources Development Corp., Boston.

Bellini E, Giori I, Ashuri O, Benelli F (1991) Geology of Al Kufra Basin, Libya. In: Salem MJ, Sbeta AM, Bakbak MR (eds) The Geology of Libya, vol. 6, Elsevier, Amsterdam, pp 2155-2184.

Bishop AN, Philp RP (1994) Potential for amorphous kerogen formation via adsorption of organic material at mineral surfaces. Energy \& Fuels 8:1494-1497.

Brenchley PJ, Carden GA, Hints L, Kaljo D, Marshall JD, Martma T, Meidla T, Nolvak J (2003) High-resolution stable isotope stratigraphy of Upper Ordovician sequences: Constraints on the timing of bioevents and environmental changes associated with mass extinction and glaciation. Geological Society of America Bulletin 115:89-104.

Brenchley PJ, Marshall JD, Harper DAT, Buttler CJ, Underwood CJ (2006) A late Ordovician (Hirnantian) karstic surface in a submarine channel, recording glacio-eustatic sea-level changes: Meifod, central Wales. Geological Journal 41:1-22.

Chabaux F, Riotte J, Dequincey O (2003) U-Th-Ra fractionation during weathering and river transport. In: Bourdon B, Henderson GM, Lundstrom CC, Turner SP (eds) Uranium-series Geochemistry. Reviews in Mineralogy and Geochemistry 52, pp 533-576.

Fello N, Lüning S, Storch P, Redfern J (2006) Identification of early Llandovery (Silurian) anoxic palaeodepressions at the western margin of the Murzuq Basin (southwest Libya), based on gamma-ray spectrometry in surface exposures. GeoArabia 11:101-118.

Füchtbauer H (1988) Sedimente und Sedimentgesteine. 4th edition, Schweizerbart, Stuttgart, 1141 pp.

Heier KS, Billings GK (1970) Potassium. In: Wedepohl KH (ed) Handbook of Geochemistry, vol. 2. SpringerVerlag, Berlin, Heidelberg, New York. Number 2, 19-K-1-19-K-4.

Jones B, Manning DAC (1994) Composition of geochemical indices used for the interpretation of paleoredox conditions in ancient mudstones. Chemical Geology 111:111-129.

Klinkhammer GP, Palmer MR (1991) Uranium in the oceans: Where it goes and why? Geochimica et Cosmochimica Acta 55:1799-1806.

Le Heron DP, Meinhold G, Page AA, Whitham A (2013) Did lingering ice sheets moderate anoxia in the Early Palaeozoic of Libya? Journal of the Geological Society London 170:327-339.

Le Heron DP, Meinhold G, Elgadry M, Abutarruma Y, Boote D (2015) Early Palaeozoic evolution of Libya: perspectives from Jabal Eghei with implications for hydrocarbon exploration in Al Kufrah Basin. Basin Research 27:60-83.

Lüning S, Kolonic S (2003) Uranium spectral gamma-ray response as a proxy for organic richness in black shales: Applicability and limitations. Journal of Petroleum Geology 26:153-174. 
Lüning S, Kolonic S, Loydell DK, Craig J (2003) Reconstruction of the original organic richness in weathered Silurian shale outcrops (Murzuq and Kufra basins, southern Libya). GeoArabia 8:299-308.

Lüning S, Craig J, Loydell DK, Storch P, Fitches B (2000) Lower Silurian 'hot shales' in North Africa and Arabia: regional distribution and depositional model. Earth-Science Reviews 49:121-200.

Lüning S, Fello N (2008) Silurian 'hot shales' in the Murzuq and Al Kufrah Basins (S Libya): Improved predictability of source rock distribution based on gamma-ray spectrometry in surface exposures. In: Salem MJ, Oun KM, Essed AS (eds) The Geology of East Libya. Sedimentary Basins of Libya - Third Symposium, vol. 4, Gutenberg Press Ltd, Malta, pp 3-12.

Meinhold G, Whitham AG, Howard JP, Stewart JC, Abutarruma Y, Thusu B (2013a) Hydrocarbon source rock potential of latest Ordovician-earliest Silurian Tanezzuft Formation shales from the eastern Kufra Basin, SE Libya. Journal of Petroleum Geology 36:105-115.

Meinhold G, Howard JP, Strogen D, Kaye MD, Abutarruma Y, Elgadry M, Thusu B, Whitham AG (2013b) Hydrocarbon source rock potential and elemental composition of lower Silurian subsurface shales of the eastern Murzuq Basin, southern Libya. Marine and Petroleum Geology 48:224-246.

Merkel RH (1979) Well log formation evaluation. AAPG Continuing Education Course Note Series 14:1-82.

Page AA, Meinhold G, Le Heron DP, Elgadry M (2013) Normalograptus kufraensis, a new species of graptolite from the western margin of the Kufra Basin, Libya. Geological Magazine 150:743-755.

Paris F, Thusu B, Rasul S, Meinhold G, Strogen D, Howard JP, Abutarruma Y, Elgadry M, Whitham AG (2012) Palynological and palynofacies analysis of early Silurian shales from borehole CDEG-2a in Dor el Gussa, eastern Murzuq Basin, Libya. Review of Palaeobotany and Palynology 174:1-26.

Raiswell R, Berner RA (1987) Organic carbon losses during burial and thermal maturation of normal marine shales. Geology 15:853-856.

Semião A, Rossiter HMA, Schäfer AI (2010) Impact of organic matter and speciation on the behaviour of uranium in submerged ultrafiltration. Journal of Membrane Science 348:174-180.

Serra O (1984) Fundamentals of Well-Log Interpretation, 1: The Acquisition of Logging Data. Developments in Petroleum Science 15:1-423.

Stocks AE, Lawrence SR (1990) Identification of source rocks from wireline logs. In: Hurst A, Lovell MA, Morton AC (eds) Geological Applications of Wireline Logs. Geological Society London, Special Publication 48, pp 241-252.

Taylor SR, McLennan SM (1985) The Continental Crust: its Composition and Evolution. Blackwell, Oxford, 307 $\mathrm{pp}$

Thusu B, Rasul S, Paris F, Meinhold G, Howard JP, Abutarruma Y, Whitham AG (2013) Latest Ordovicianearliest Silurian acritarchs and chitinozoans from subsurface samples in Jebel Asba, Kufra Basin, SE Libya. Review of Palaeobotany and Palynology 197:90-118.

Wignall PB, Myers KJ (1988) Interpreting the benthic oxygen levels in mudrocks, a new approach. Geology $16: 452-455$.

Wignall PB, Twitchett RJ (1996) Oceanic anoxia and the end Permian mass extinction. Science 272:1155-1158.

Worden RH, Morad S (2003) Clay minerals in sandstones: controls on formation, distribution and evolution. In: Worden RH, Morad S (eds) Clay mineral cements in sandstones. International Association of Sedimentologists, Special Publication 34, pp 3-41.

Xu C, Jia-yu R, Yue L, Boucot AJ (2004) Facies patterns and geography of the Yangtze region, South China, through the Ordovician and Silurian transition. Palaeogeography, Palaeoclimatology, Palaeoecology 204:353-372.

\section{FIGURE CAPTIONS}

Fig. 1 Landsat image (NASA Landsat Program) of Jabal Eghei in the western Kufra Basin showing localities where hand-held gamma ray spectrometry measurements were carried out. The inset shows the location of Jabal Eghei in SE Libya and the CASP boreholes CDEG-2a (Meinhold et al. 2013b; Paris et al. 2012) and JA-2 (Meinhold et al. 2013a; Thusu et al. 2013)

Fig. 2 Generalised stratigraphic column for Ordovician-Silurian and Mesozoic strata in Jabal Eghei, western Kufra Basin, SE Libya, with main lithologies, thicknesses and petroleum system elements (compiled after Le Heron et al. 2013, 2015; Page et al. 2013) 
Fig. 3 Schematic stratigraphic column to illustrate the three different members of the Tanezzuft Formation distinguished by hand-held gamma-ray measurements in Jabal Eghei, western Kufra Basin, SE Libya. The upper member starts with a graptolite-bearing marker bed. Note the numbers in brackets refer to numbers in the text. A detailed description of the section is provided in Le Heron et al. $(2013,2015)$

Fig. 4 (a) Field photo looking eastwards to the main section through the latest Ordovician-earliest Silurian Tanezzuft Formation in Jabal Eghei, western Kufra Basin, SE Libya. (b) Field photo showing upper member of the Tanezzuft Formation overlain by Mesozoic sandstone

Fig. 5 Hand-held gamma ray measurements of latest Ordovician-early Silurian sediments and Mesozoic sandstone at Jabal Eghei, western Kufra Basin, SE Libya. MB - Marker bed (red-brown colour, Fe rich, in some places graptolite bearing), marked with number 6 on Fig. 3

Fig. 6 Hand-held gamma ray measurements of latest Ordovician-early Silurian sediments and Mesozoic sandstone at Jabal Eghei, western Kufra Basin, SE Libya. MB - Marker bed (red-brown colour, Fe rich, in some places graptolite bearing), marked with number 6 on Fig. 3

Fig. 7 Cross plots. (a) U versus K, (b) Th/U versus K, (c) Th versus U, (d) Th/U versus U for all measured mudrock and sandstone exposures. (e) U versus K, (f) Th/U versus K, (g) Th versus U, (h) Th/U versus U for all measured sandstone exposures

Fig. 8 Cross plots. (a) U versus K, (b) Th/U versus K, (c) Th versus U, (d) Th/U versus U, (e) Th versus K for all measured Tanezzuft Formation exposures. (f) Th versus K for mineral identification (after Bateman, 1985). Wignall and Twitchett (1996) have suggested that environments characterised by anoxic conditions lead to mudrock $\mathrm{Th} / \mathrm{U}$ ratios of 0 to 2 . Uranium values of 10-30 ppm suggest the presence of "warm shales" (e.g., Lüning et al. 2000; Lüning and Fello 2008)

Fig. 9 Summary plot of U versus Th/K for all Tanezzuft Formation exposures of Jabal Eghei, western Kufra Basin, SE Libya, showing that uranium enrichment is related here to kaolinite-rich mudrocks with high total clay content. See Fig. 8E-F for definition of kaolinite field

Fig. 10 Environmental process diagram for the latest Ordovician-earliest Silurian Tanezzuft Formation section at Jabal Eghei, western Kufra Basin, SE Libya. The relative sea-level curve was taken from Le Heron et al. (2013). This curve takes into account the progressive upsection loss of hummocky cross-stratification and increase in mud content, compatible with a deepening trend. Ice presence is interpreted on the basis of soft-sediment striae and/or ?dropstones and manganese oxide concretions (see Le Heron et al. 2013). Anoxia is inferred on the basis of faunal preservation in the graptolite assemblage (Page et al. 2013) and on chemical parameters such as $\mathrm{Th} / \mathrm{U}<2$ and presence of authigenic $U$ (this study) 


\section{Figure 1}

Click here to download Figure: Fig1.tif

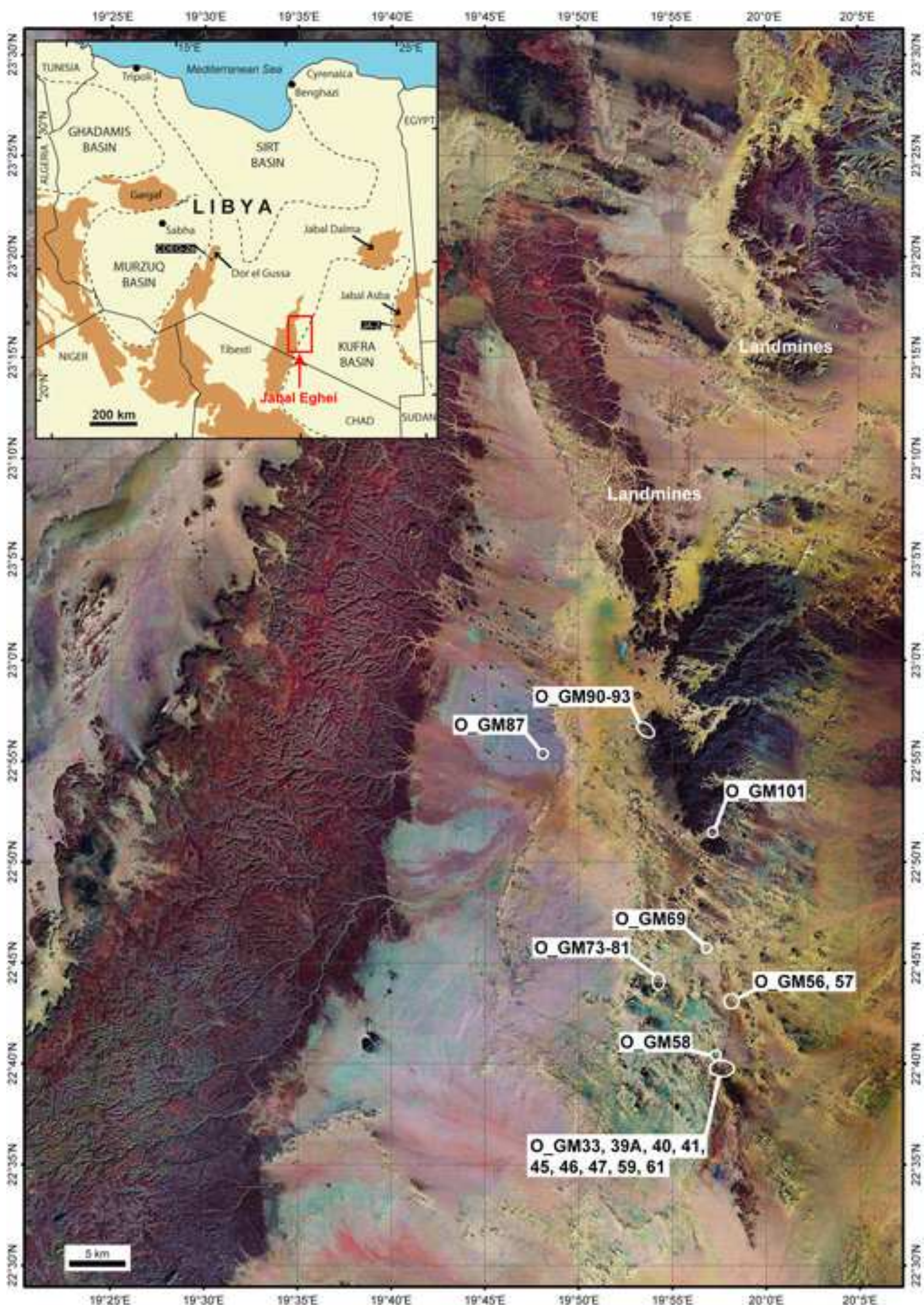




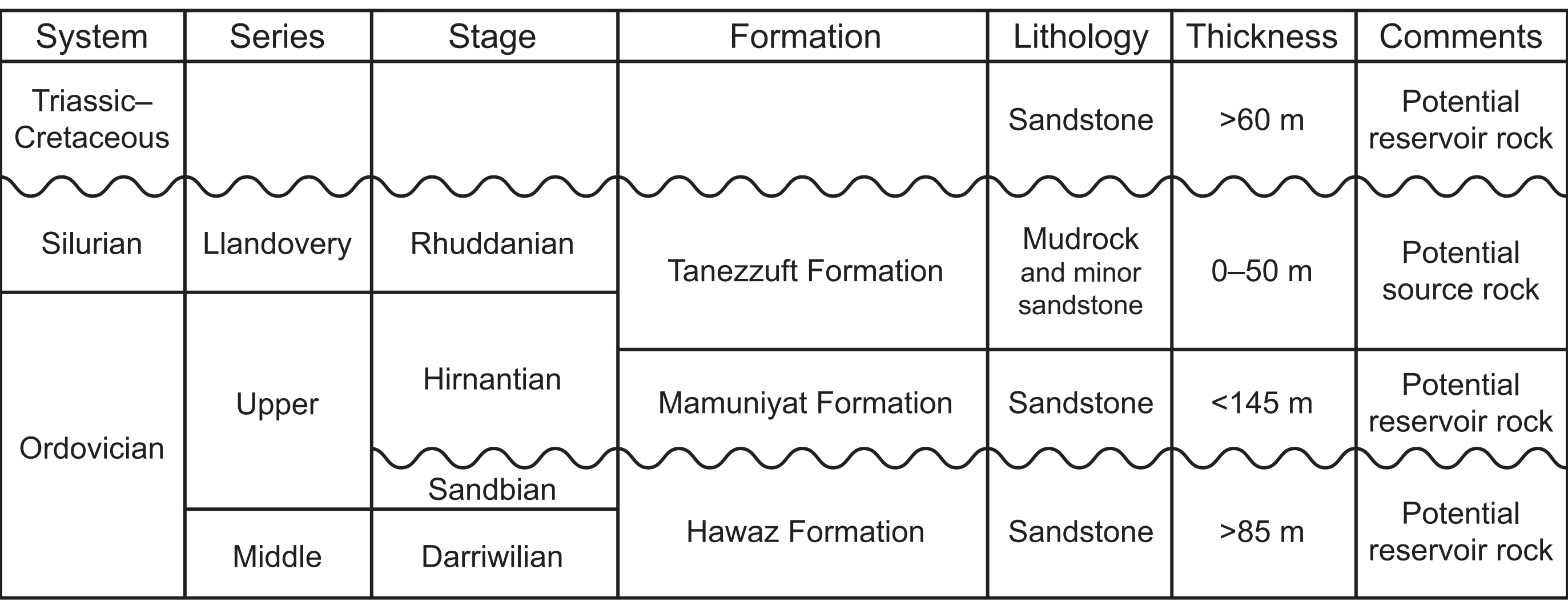


(m) Schematic profile

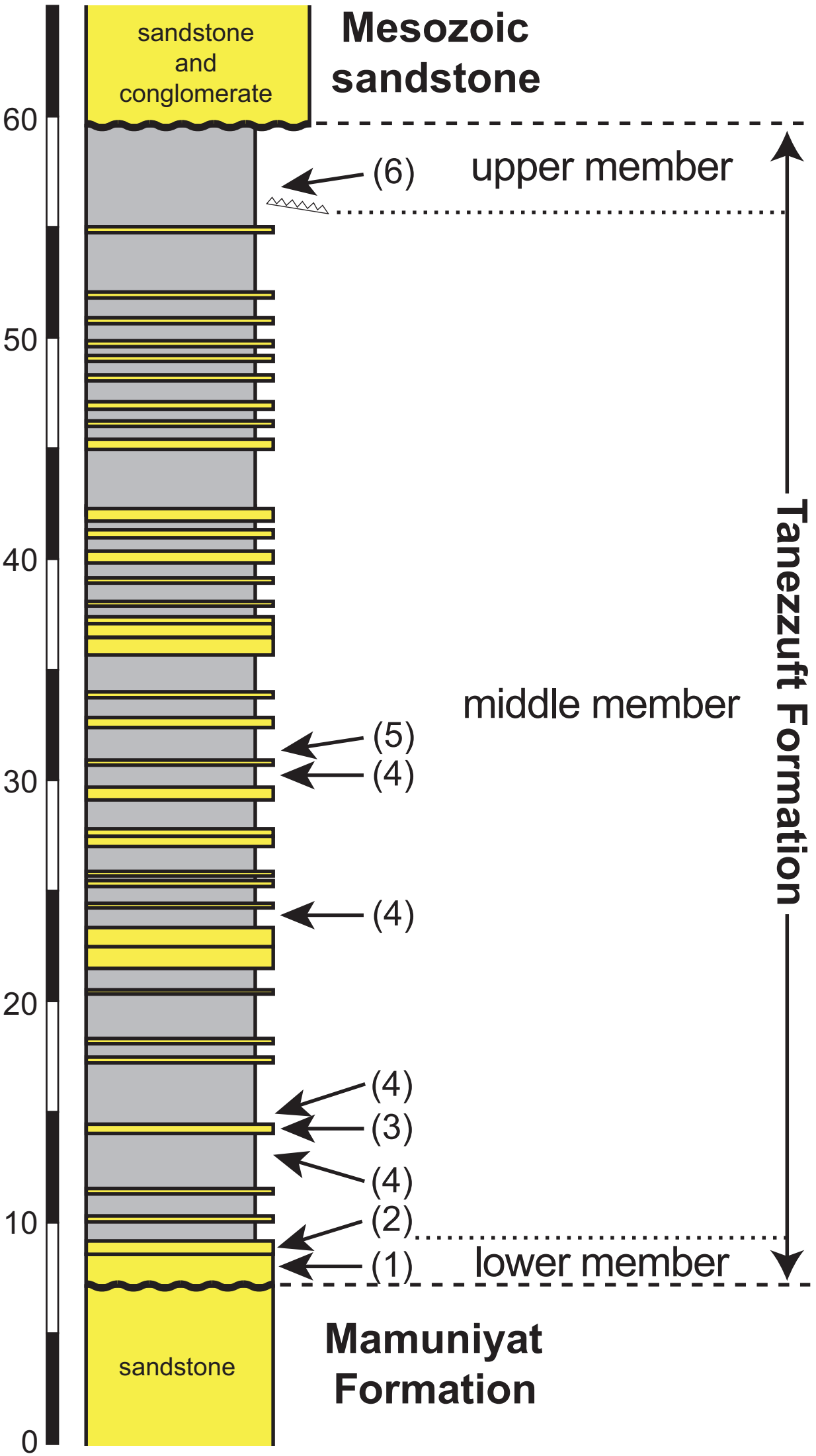

\section{KEY}

Graptolites

$\square$ Mudrock

$\square$ Sandstone

(1) Bryozoa-bearing sandstone

(2) Planolites horizon

(3) Striated surface

(4) Pebble layers (?dropstones)

(5) Planolites horizon

(6) graptolite-bearing marker bed 


\section{A}

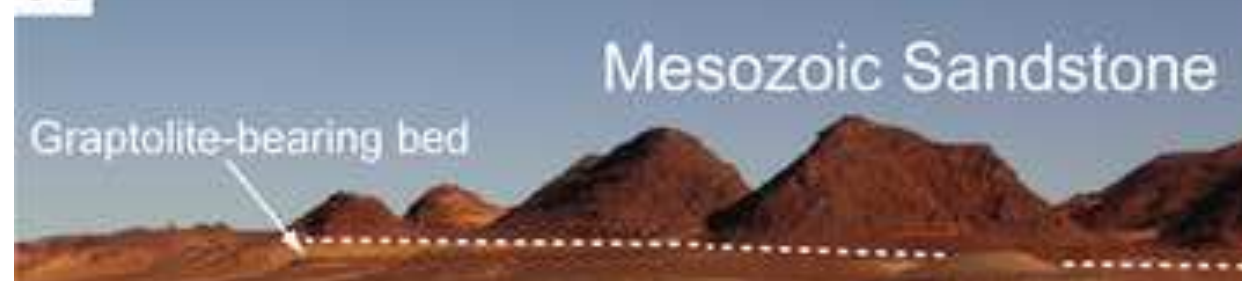

Tanezzuft Formation

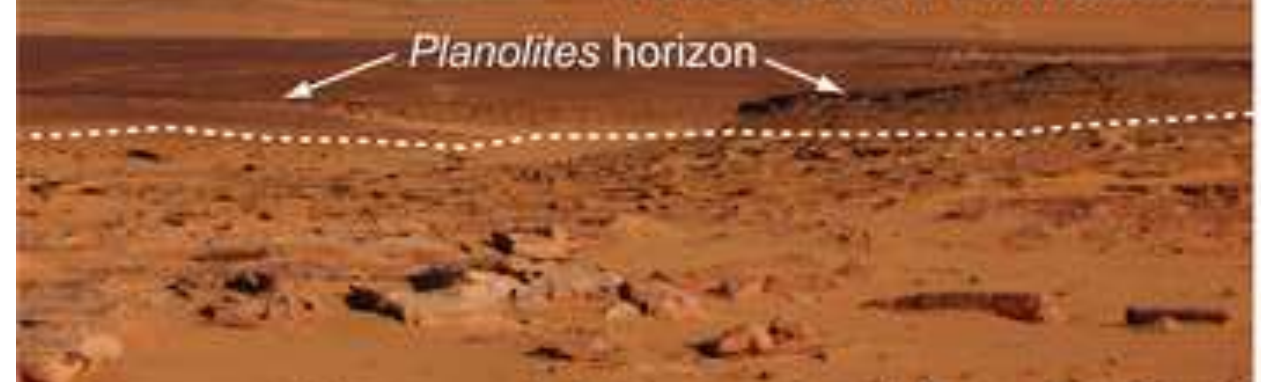

topmost Mamuniyat Formation
B

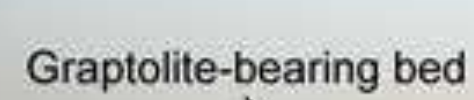

Graptolite-bearing bed

Tanezzuft Formation

\section{Mesozoic Sandstone}

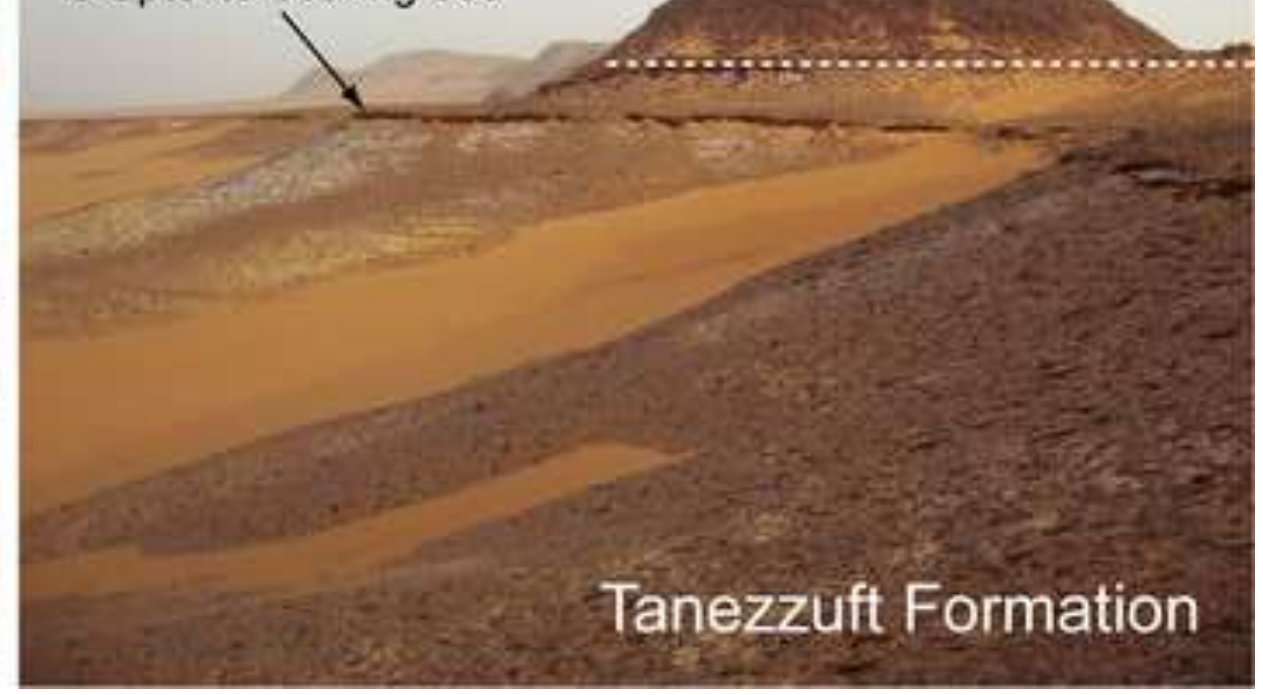


Figure 5
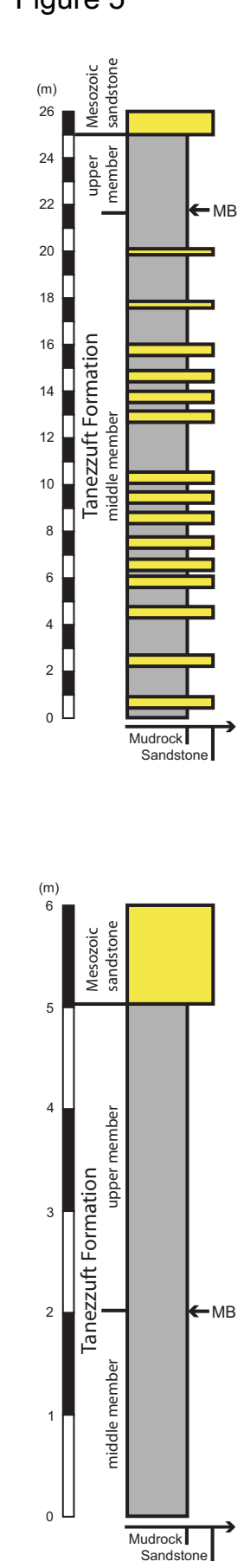

andstone

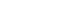

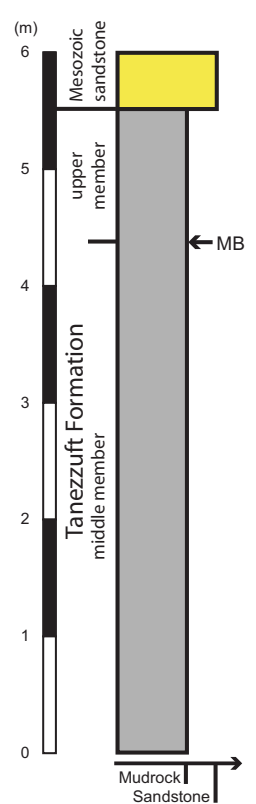

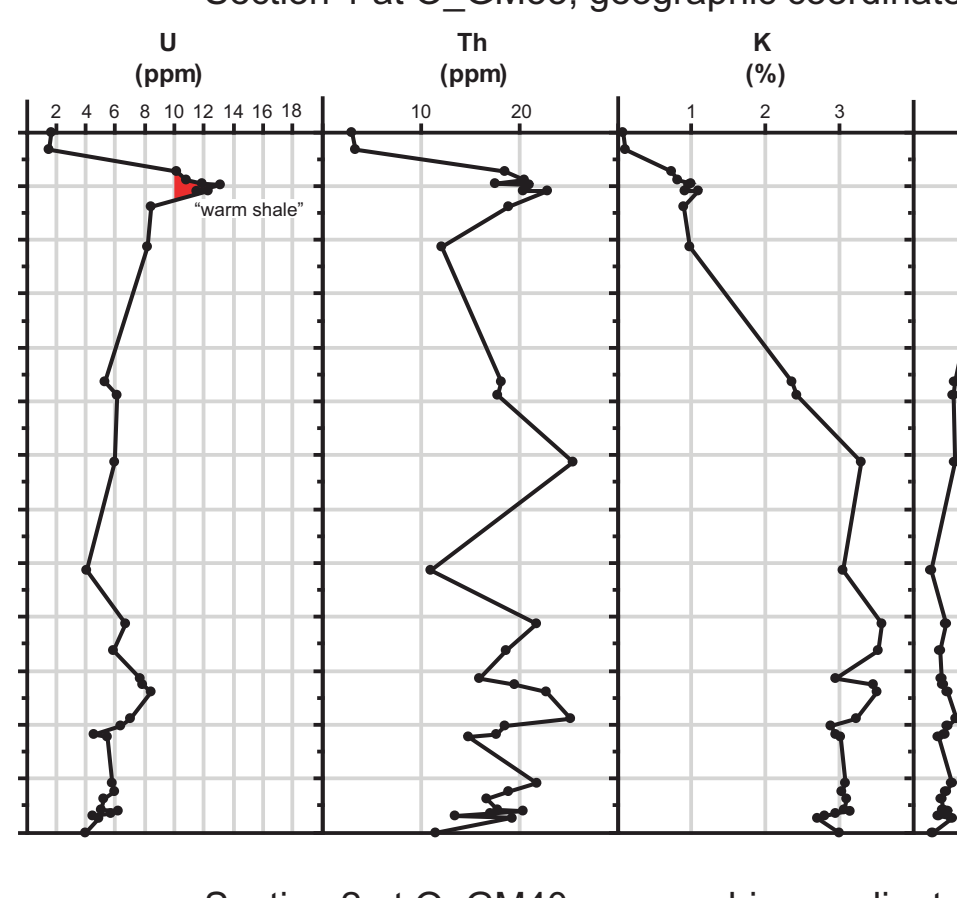

$\mathrm{Th} / \mathrm{K}$

$\mathrm{Th} / \mathrm{U}$

Section 2 at O_GM40; geographic coordinates: $22^{\circ} 39^{\prime} 46.4^{\prime \prime} \mathrm{N}, 1^{\circ} 57^{\prime} 47.5^{\prime \prime} \mathrm{E}$

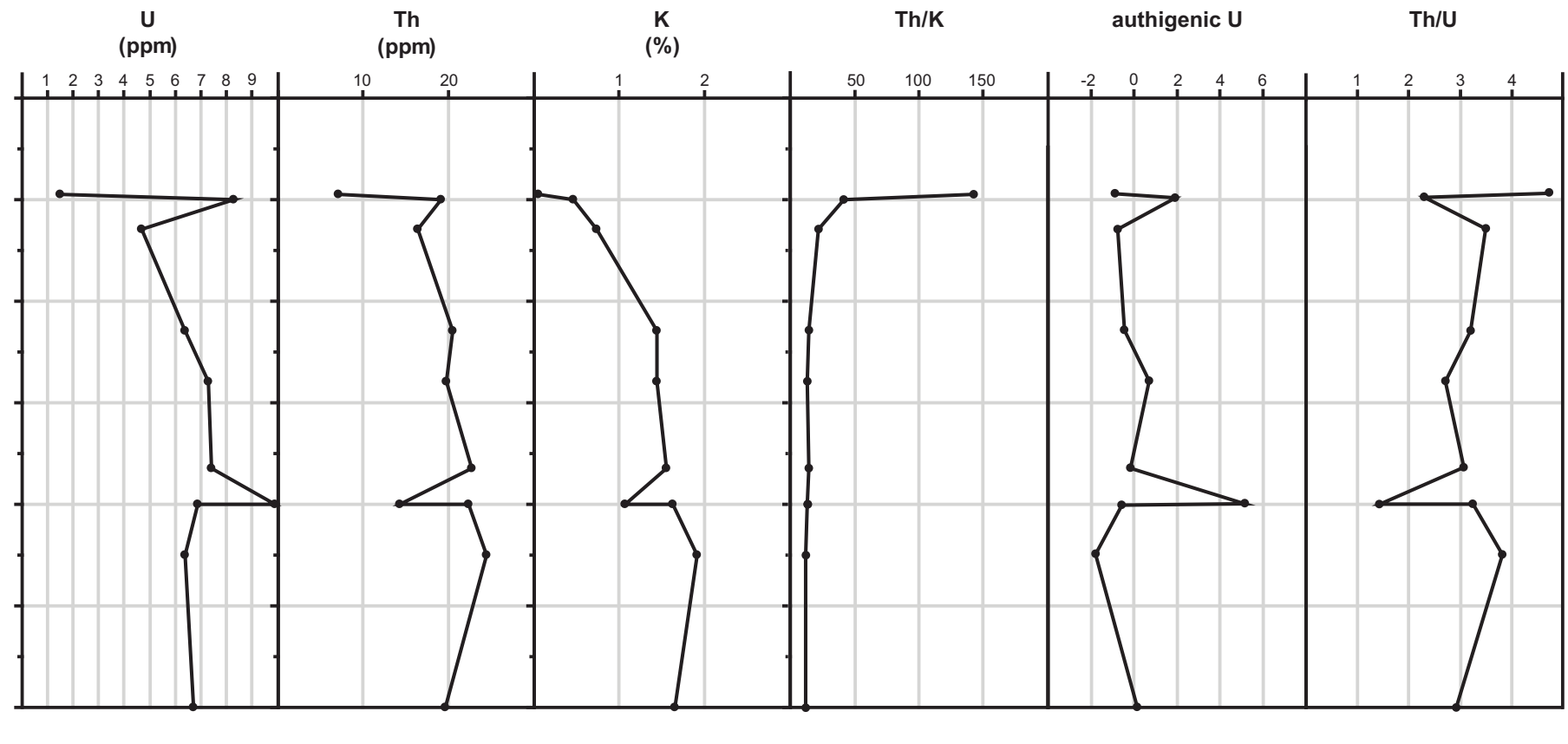

Section 3 at O_GM41; geographic coordinates: $22^{\circ} 39^{\prime} 48.4^{\prime \prime} \mathrm{N}, 19^{\circ} 57^{\prime} 49.0^{\prime \prime E}$

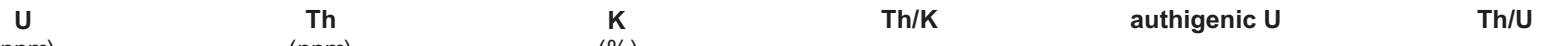

(\%)

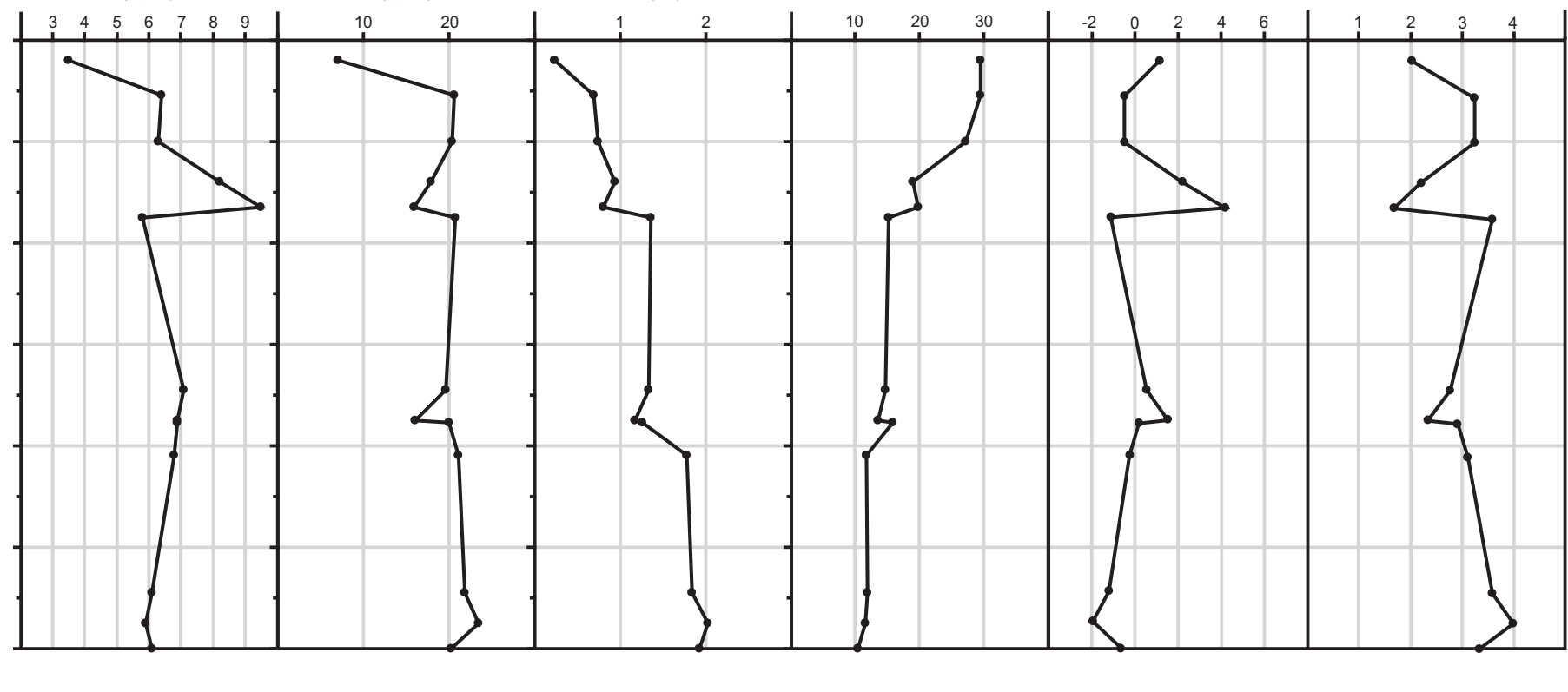


Section 4 at O_GM57; geographic coordinates: $22^{\circ} 43^{\prime} 12.3^{\prime \prime N}, 19^{\circ} 58^{\prime} 10.1{ }^{\prime \prime E}$
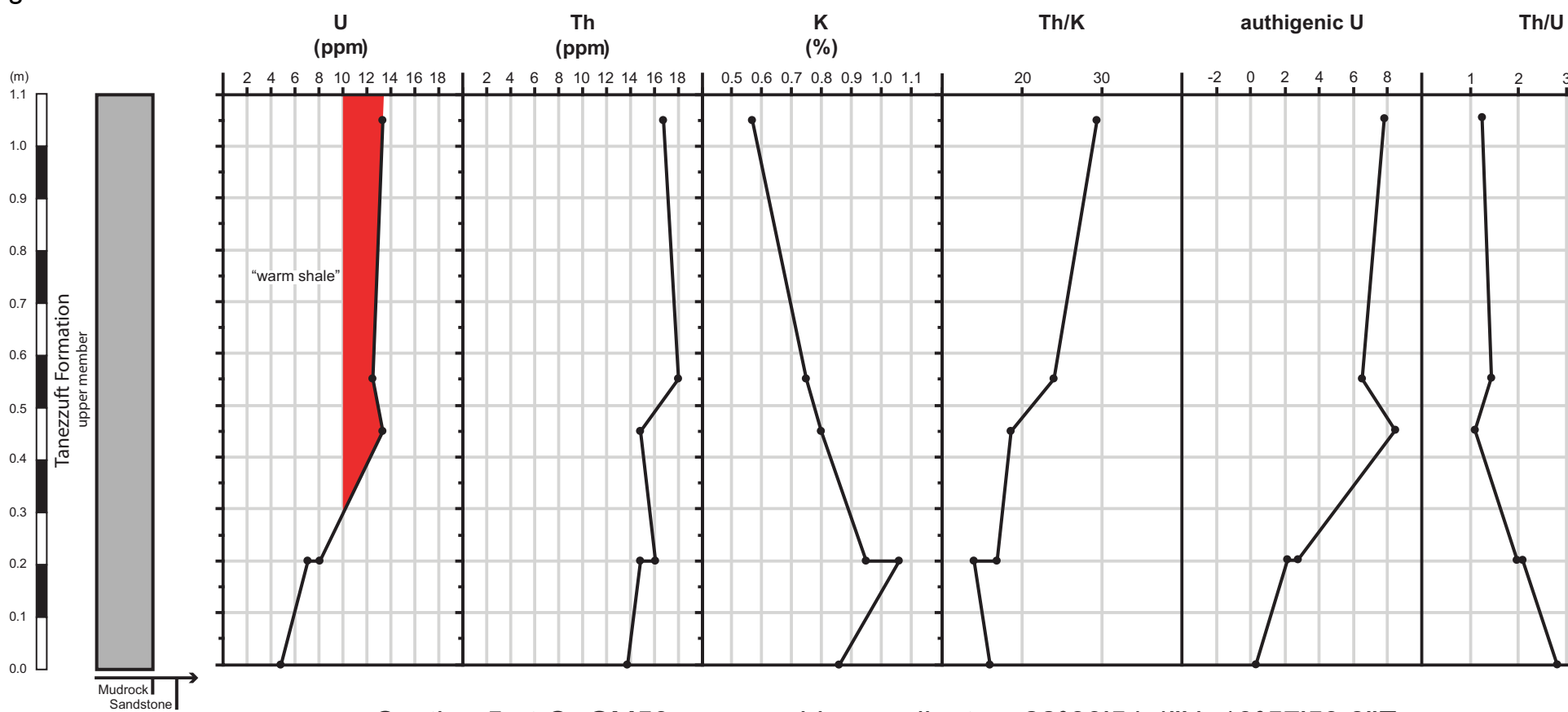

(ppm) (\%)

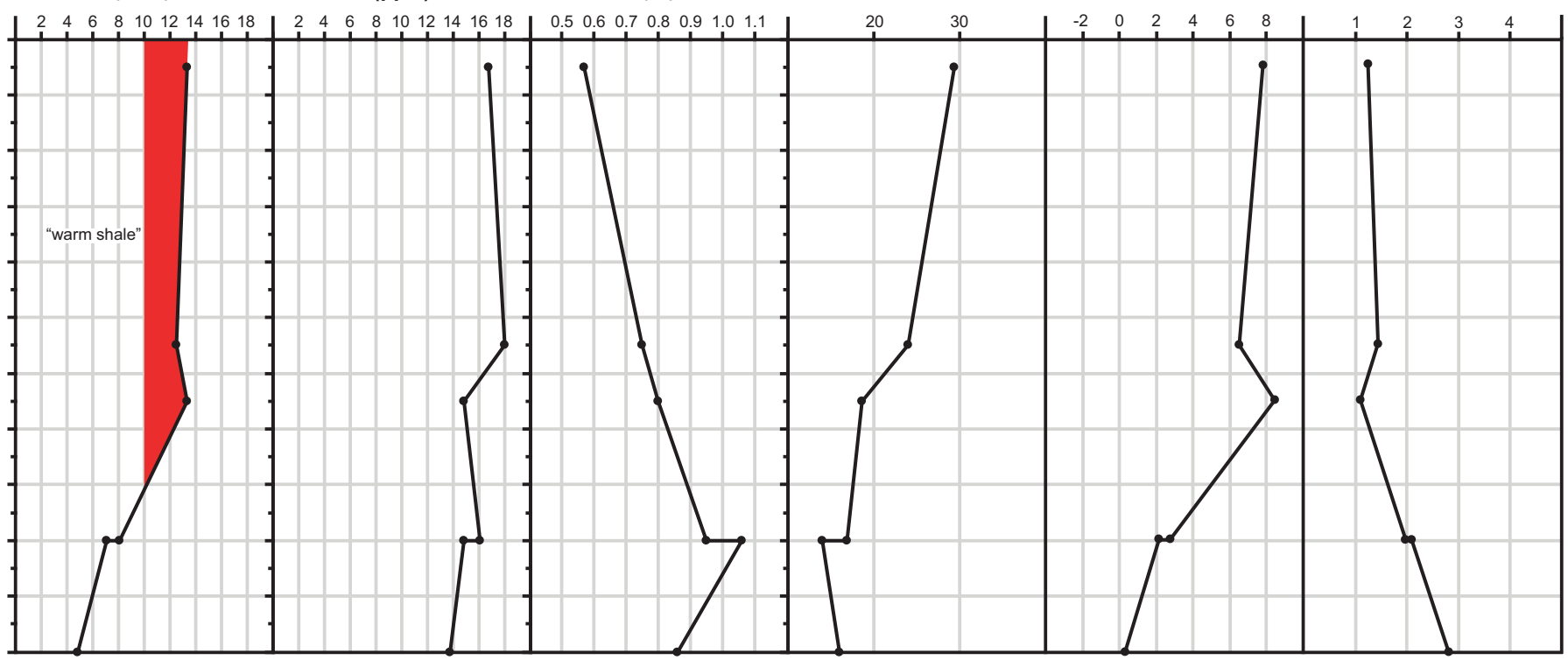

Section 5 at O_GM59; geographic coordinates: $22^{\circ} 39^{\prime} 54.4^{\prime \prime} \mathrm{N}, 19^{\circ} 57^{\prime} 59.8^{\prime \prime E}$

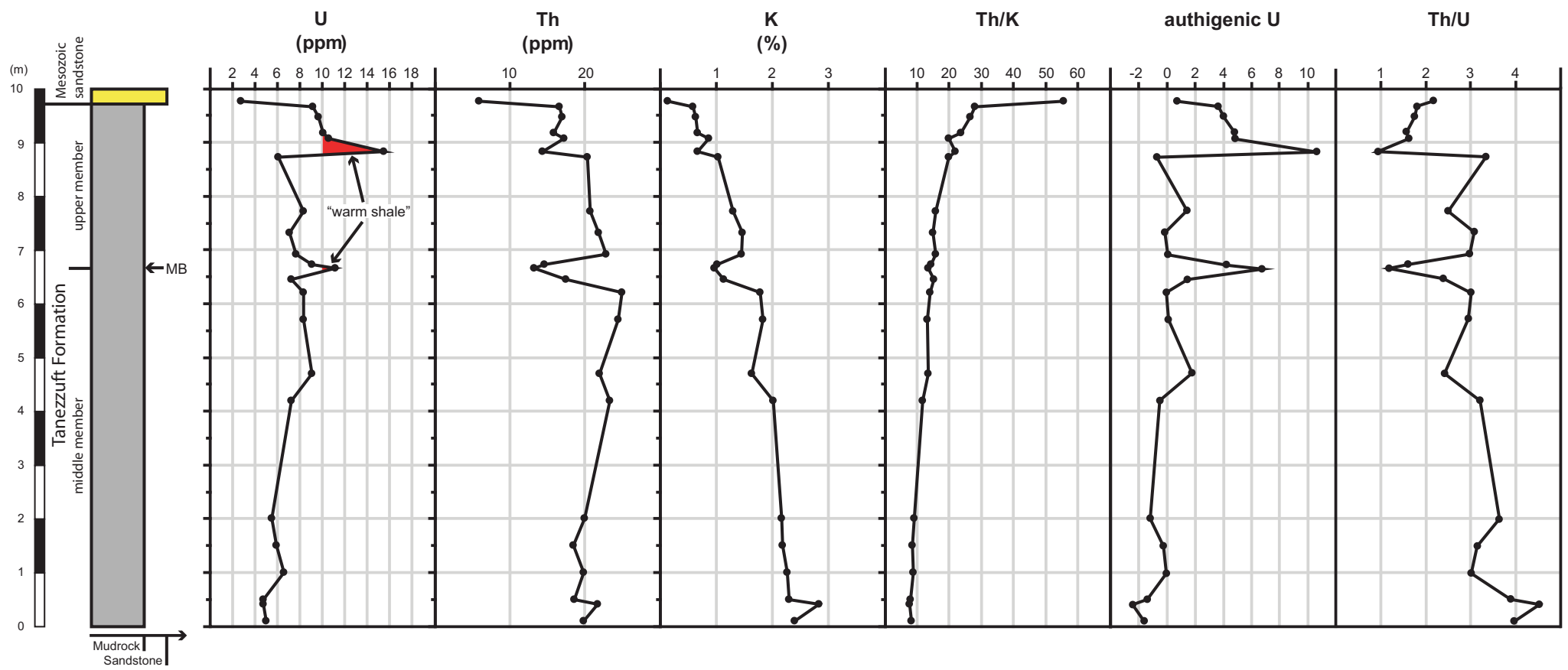

Section 6 at O_GM61; geographic coordinates: $22^{\circ} 39^{\prime} 38.0^{\prime \prime} \mathrm{N}, 1^{\circ} 57^{\prime} 43.0^{\prime \prime} \mathrm{E}$
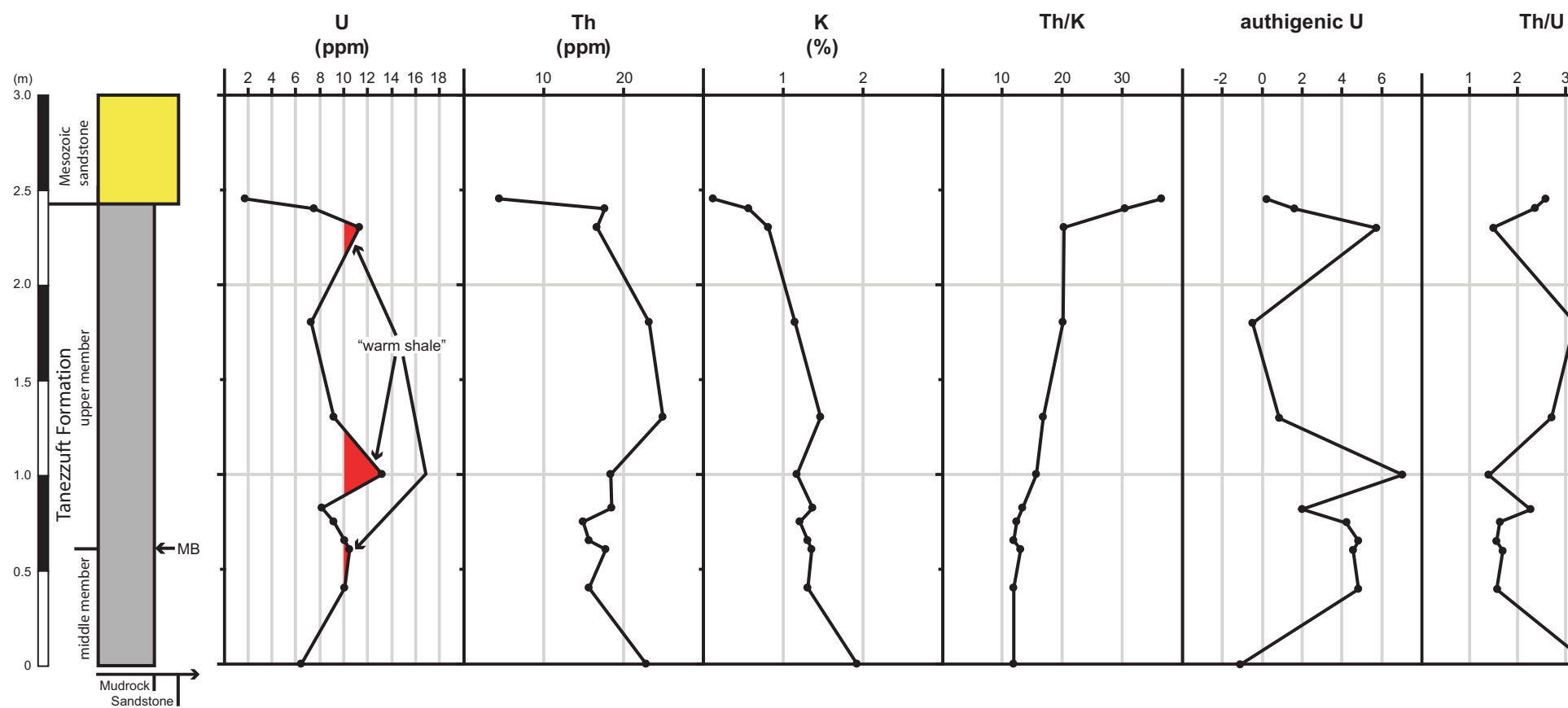

(\%)

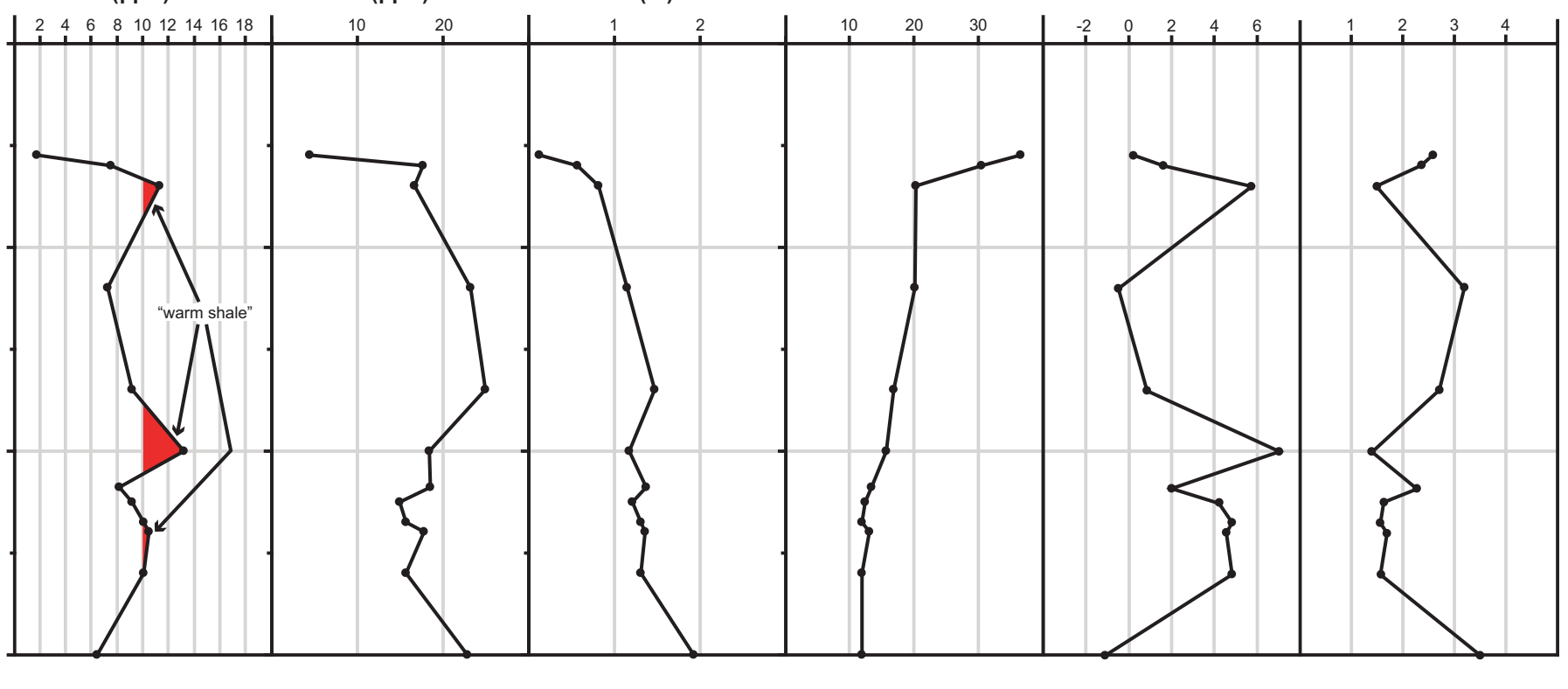



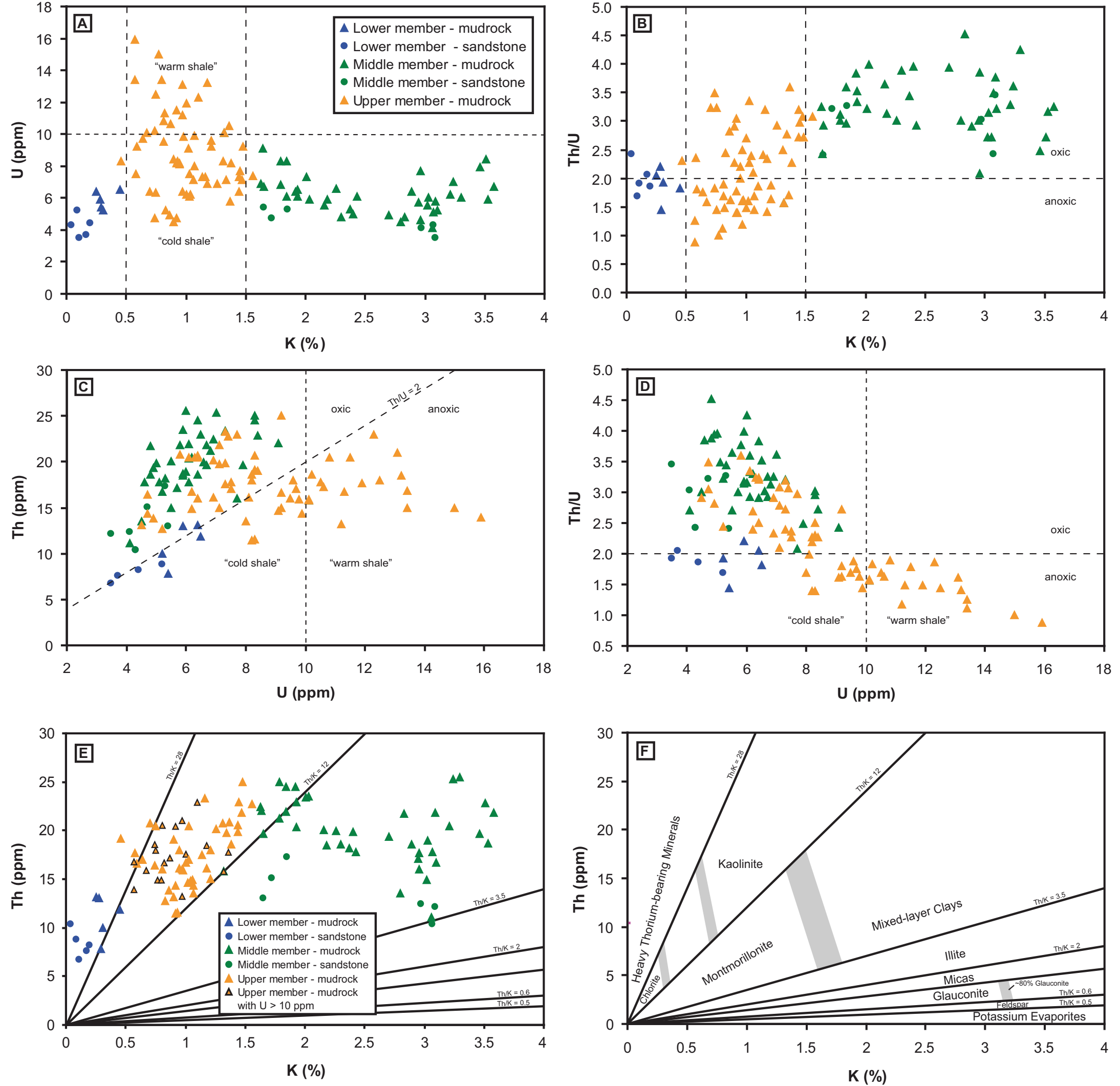


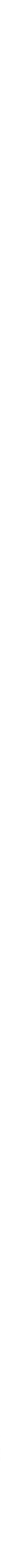


Figue ${ }^{10}$ Schematic

Stratigraphy

Source rock profile

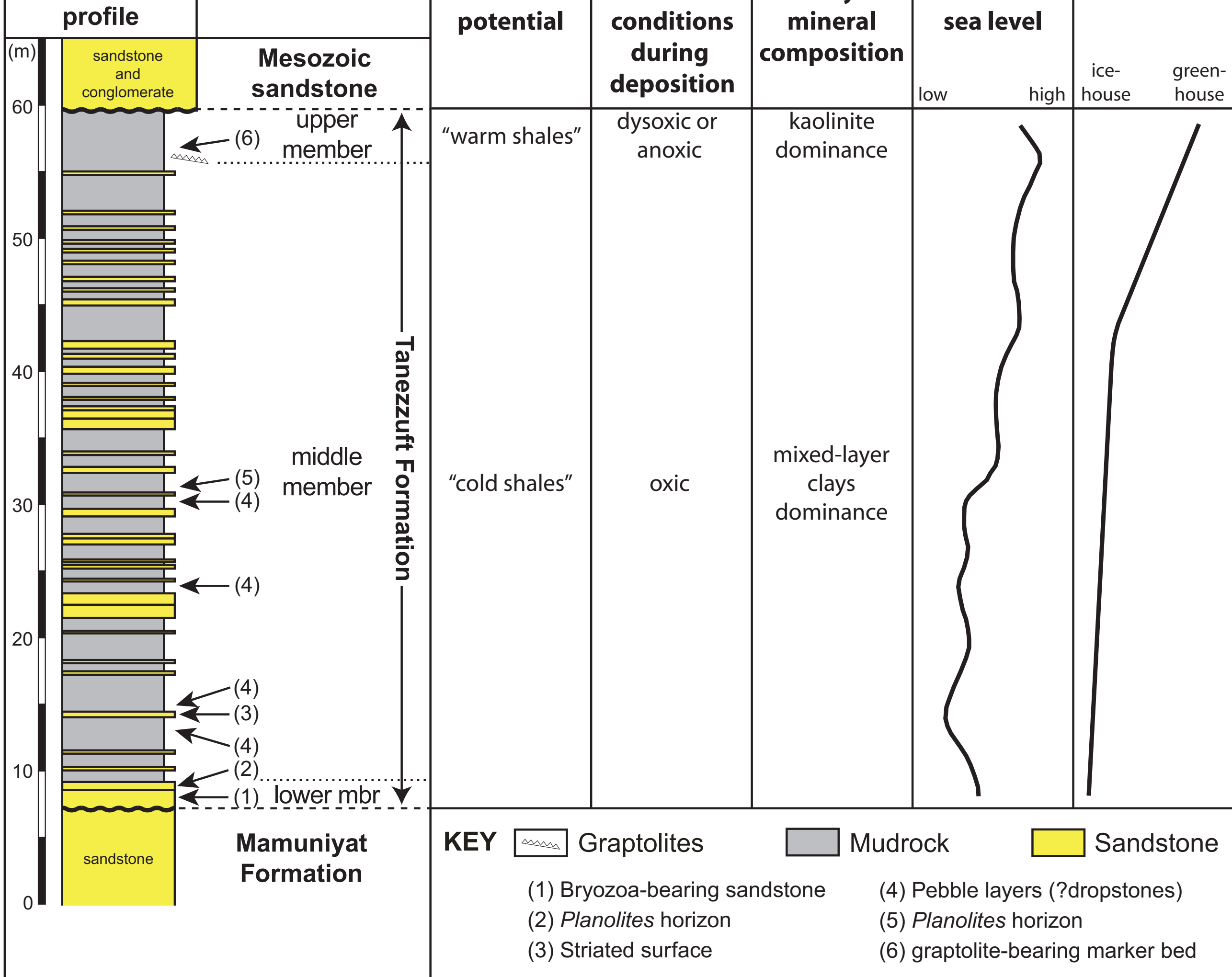


Table 1 X-ray diffraction (XRD) data (in \%) of three representative samples from the Tanezzuft Formation of Jabal Eghei, western Kufra Basin, SE Libya. Lower member: bryozoa-bearing sandstone, sample S_GM80; Middle member: fine-grained sandstone, sample S_GM77; Upper member: graptolite-bearing mudrock, sample S_GM78G10

\begin{tabular}{|c|c|c|c|}
\hline \multirow[t]{5}{*}{ Mineralogy } & \multicolumn{3}{|c|}{ Samples } \\
\hline & S_GM80 & S_GM77 & S_GM78G10 \\
\hline & Lower member & Middle member & Upper member \\
\hline & $22^{\circ} 39^{\prime} 46.6^{\prime \prime N}$ & $22^{\circ} 39^{\prime} 44.1^{\prime \prime} \mathrm{N}$ & $22^{\circ} 39^{\prime} 44.3^{\prime \prime} \mathrm{N}$ \\
\hline & $19^{\circ} 57^{\prime} 13.2^{\prime \prime} \mathrm{E}$ & $19^{\circ} 57^{\prime} 24.3^{\prime \prime} \mathrm{E}$ & $19^{\circ} 57^{\prime} 43.8^{\prime \prime} \mathrm{E}$ \\
\hline Chlorite & - & 0.6 & 1.2 \\
\hline Dolomite & - & - & - \\
\hline Goethite & 1 & - & 18.6 \\
\hline Hematite & - & 5.6 & 7.7 \\
\hline Illite & - & 13.4 & 21.1 \\
\hline Kaolinite & 17.4 & 16.8 & 28.3 \\
\hline K-feldspar & - & 6.7 & - \\
\hline Pyrite & 0.1 & - & 0.4 \\
\hline Quartz & 83.8 & 53.4 & 22.1 \\
\hline Total clay & 17.4 & 30.8 & 50.6 \\
\hline SUM & 102.3 & 96.5 & 99.4 \\
\hline
\end{tabular}

Note that the precision is about $\pm 5 \%$ for clays and $\pm 1-2 \%$ for the other minerals. Minerals quoted as present, but with a total of $<1 \%$ ( $<5 \%$ for clays), are close to the detection limit. 
Table 2 U, Th and K concentrations in common mineral phases (after Merkel 1979; Batman 1985)

\begin{tabular}{lccc}
\hline Mineral & K $(\boldsymbol{\%})$ & $\mathbf{U}(\mathbf{p p m})$ & Th $(\mathbf{p p m})$ \\
\hline Quartz & $<0.15$ & - & $<0.2$ \\
Plagioclase & 0.54 & - & $<0.01$ \\
Orthoclase & $11.8-14.0$ & - & $<0.01$ \\
Montmorillonite & 0.16 & $2-5$ & $14-24$ \\
Kaolinite & 0.42 & $1.5-3$ & $6-19$ \\
Illite & 4.5 & 1.5 & - \\
Biotite & $6.7-8.3$ & - & $<0.01$ \\
Muscovite & $7.9-9.8$ & - & $<0.01$ \\
Monazite & - & $500-3000$ & $2.5 \times 10^{4}-20 \times 10^{4}$ \\
Zircon & - & $300-3000$ & $100-2500$ \\
\hline
\end{tabular}

